\title{
Andrographis paniculata in the Treatment of Upper Respiratory Tract Infections: A Systematic Review of Safety and Efficacy
}

Joanna Thompson Coon Edzard Ernst

\begin{abstract}
Acute respiratory infections represent a significant cause of overprescription of antibiotics and are one of the major reasons for absence from work. The leaves of Andrographis paniculata (Burm.f.) Wall ex Nees (Acanthaceae) are used as a medicinal herb in the treatment of infectious diseases. Systematic literature searches were conducted in six computerised databases and the reference lists of all papers located were checked for further relevant publications. Information was also requested from manufacturers, the spontaneous reporting schemes of the World Health Organisation and national drug safety bodies. No language restrictions were imposed. Seven double-blind, controlled trials $(n=896)$ met the inclusion criteria for evaluation of efficacy. All trials scored at least three, out of a maximum of five, for
\end{abstract}

methodological quality on the Jadad scale. Collectively, the data suggest that $A$. paniculata is superior to placebo in alleviating the subjective symptoms of uncomplicated upper respiratory tract infection. There is also preliminary evidence of a preventative effect. Adverse events reported following administration of $A$. paniculata were generally mild and infrequent. There were few spontaneous reports of adverse events. A. paniculata may be a safe and efficacious treatment for the relief of symptoms of uncomplicated upper respiratory tract infection; more research is warranted.

\section{Key words}

Medicinal plants · herbal medicine - upper respiratory infections . systematic review $\cdot$ Andrographis paniculata $\cdot$ Acanthaceae

\section{Introduction}

In the UK, an acute respiratory infection is the commonest reason for a patient to consult a general practitioner. Thirty million courses of antibiotics are prescribed per year for the treatment of acute respiratory infections [1], despite evidence that they neither shorten the course of acute viral infections nor prevent secondary bacterial infections [2]. The overuse of antimicrobial drugs for the management of respiratory infections has important implications for healthcare costs and the potential for emergence of antimicrobial resistance [3].

In light of the continued popularity of herbal medicine [4], an effective and well-tolerated herbal medication for the preven- tion and treatment of acute respiratory infections would be a welcome addition to the therapeutic repertoire. The leaves of Andrographis paniculatam, popular in Scandinavia as a cold and influenza remedy, are used traditionally in Ayurvedic, Thai and Chinese medicine to treat fever associated with infectious diseases. Pharmacological studies suggest anti-inflammatory [5], [6], antipyretic [7], [8], antiviral [9] and immunostimulatory [10] properties. The aim of this review was to systematically assess the efficacy and safety of $A$. paniculata in the treatment and prevention of upper respiratory tract infections. 


\section{Methods}

\section{Identification of clinical trials}

In order to identify all reports of administration of Andrographis paniculata to human subjects, systematic literature searches were conducted in the following electronic databases: Medline (Via Pubmed), Embase, CINAHL, Amed (Alternative and Allied Medicine Database, British Library Medical Information Centre), The Cochrane Library (Issue 2, 2003), and the British Library Index of Conference Proceedings (all from their inception to June 2003). The search terms used were: Andrographis paniculata, kalmegh, kiryat, chuanxinlian, chiretta, fa-tha-lai-jone and Kan Jang. Further relevant papers were located by hand-searching the reference lists of all papers and departmental files. Hand searching of standard reference texts [11], [12] and internet searches revealed four manufacturers/distributors of $A$. paniculata products who were contacted and asked to supply any published or unpublished material.

\section{Adverse event reports}

Data were requested from the following spontaneous reporting schemes: the World Health Organisation (Uppsala Monitoring Centre), and the drug safety bodies of the United Kingdom (Medicines Control Agency), Australia (Adverse Drug Reactions Advisory Committee) and Germany (Bundesinstitut für Arzneimittel und Medizinprodukte).

\section{Inclusion and exclusion criteria}

For the evaluation of efficacy, only double-blind, controlled clinical trials of the oral administration of single or combination preparations of A. paniculata for the treatment of uncomplicated upper respiratory tract infection (URTI) were included. All retrieved data including uncontrolled trials, case reports, pre-clinical and observational studies and clinical trials for other indications were included in the review of safety. No language restrictions were imposed.

\section{Data extraction and quality assessment}

All articles were read in full. Data relating to sample size, study design, intervention and control, treatment duration, primary outcome measures, number and type of adverse events and results were extracted according to predefined criteria. The methodological quality of each clinical trial was assessed using the Jadad scoring system [13]; a scale ranging from 0 (poorest) to 5 (highest) which assesses methods of randomisation and blinding and the description of withdrawals and dropouts.

Study selection, data extraction and assessment of methodological quality were performed by the first reviewer and validated by the second, with any disagreements being settled by discussion.

\section{Results}

A total of 143 references were retrieved from the systematic literature searches; eleven papers described the administration of A. paniculata to human subjects. These included four doubleblind, controlled clinical trials of the treatment of uncomplicated URTI (three further eligible trials were identified from reference lists and our own departmental files) (Table 1) [14], [15], [16],
[17], [18], a phase I trial in HIV positive and negative patients [20], two studies in healthy volunteers [21], [22], and three case series [23], [24], [25]. Adverse events reported within these twelve papers are shown in Table 2.

\section{Evaluation of efficacy}

Seven double-blind, controlled trials $(\mathrm{n}=896)$ met the inclusion criteria [14], [15], [16], [17], [18], [19]. Of these, five were randomised and six were placebo-controlled; one compared the effects of Andrographis paniculata with paracetamol. All trials scored at least three out of five points for methodological quality.

Melchior et al. in 2000 conducted two randomised, double-blind, placebo-controlled parallel group clinical trials of a fixed combination of standardised extracts of the leaves of $A$. paniculata (60 mg andrographolide/day) and the roots of Eleutherococcus senticosus (Rupr. \& Maxim) Maxim (120 mg/day) in 47 and 180 adult patients with uncomplicated acute URTI treated within 36 hours of the onset of symptoms [18]. Primary outcome measures were patient and physician evaluation of the severity of pre-defined signs and symptoms (e.g., muscle pain, cough, throat, nasal and eye signs and symptoms and temperature). In the larger study, there was a significantly greater improvement in both patient $(p=0.0006)$ and physician $(p=0.003)$ evaluated total symptom scores in the treatment group compared with placebo, after three days. Analysis of individual symptoms showed significant differences in muscle soreness, cough frequency, presence of a productive cough, body temperature and dry throat. The smaller, pilot study showed a non-significant reduction in patient evaluated total symptom score in the treated group, compared with placebo $(\mathrm{p}=0.08)$. Physician symptom evaluation was not reported.

Two hundred men and women with a diagnosis of upper respiratory tract infection (not requiring treatment with antibiotics) were treated with either a fixed combination of $A$. paniculata (60 mg andrographolide/day) and E. senticosus (120 mg/day) or placebo for five days in a non-randomised, double-blind, parallel group study performed in two centres in the Republic of Armenia [15]. Clinical observations included evaluation of the following signs and symptoms, rhinitis, sinusitis, pharyngitis, fever, abnormal pulmonary findings, lymphadenopathy, nasal discharge and stuffiness, sore throat, earache, cough and headache. Although there was a significant difference in mean symptom scores between groups at baseline (treatment 0.65 vs. placebo 0.82 ; $\mathrm{p}=0.006$ ) there was also a highly significant difference at the end of treatment (treatment 0.09 vs. placebo $0.63 ; \mathrm{p}<0.001$ ). Subsequent statistical analyses suggest that although the baseline mean score affected the mean score post-treatment, it did not interfere with the observed difference in improvement between the two groups. The baseline difference was thought to be due to differences in the type of patients recruited at the two centres; one of which was an emergency department and the other an outpatient clinic. Headache, nasal and throat symptoms and general malaise showed the most improvement, whilst cough and eye symptoms did not differ between the groups.

In a randomised, placebo-controlled double-blind study of 208 adult patients diagnosed with uncomplicated URTI (ICPC classification), Caceres et al. collected patient self-evaluations of head- 
Table 1 Double-blind, controlled trials of Andrographis paniculata for the treatment of uncomplicated URTI

\begin{tabular}{|c|c|c|c|c|c|c|c|c|}
\hline $\begin{array}{l}\text { First author } \\
\text { (reference) }\end{array}$ & $\begin{array}{l}\text { Quality } \\
\text { score }\end{array}$ & $\begin{array}{l}N \\
\text { (rando- } \\
\text { mised/ } \\
\text { analysed) }\end{array}$ & $\begin{array}{l}\text { Study } \\
\text { design }\end{array}$ & $\begin{array}{l}\text { Type of } \\
\text { preparation }\end{array}$ & $\begin{array}{l}\text { Daily dose } \\
\text { of androgra } \\
\text { pholide } \\
\text { (mg) }\end{array}$ & $\begin{array}{l}\text { Duration } \\
\text { (days) }\end{array}$ & $\begin{array}{l}\text { Delay } \\
\text { between } \\
\text { onset of } \\
\text { symptoms } \\
\text { and start } \\
\text { of therapy } \\
\text { (hours) }\end{array}$ & Main results \\
\hline $\begin{array}{l}\text { Melchior } \\
\text { [18] }\end{array}$ & 5 & $180 / 179$ & $\begin{array}{l}\mathrm{R}, \mathrm{PC} \\
\text { treatment }\end{array}$ & $\begin{array}{l}\text { standardised } \\
\text { extract; } \\
\text { AP/ES } \\
\text { combination }\end{array}$ & 60 & 3 & 36 & $\begin{array}{l}\text { greater improvement in patient's } \\
(p=0.0006) \text { and physician's } \\
(p=0.003) \text { overall symptom score } \\
\text { compared with placebo }\end{array}$ \\
\hline $\begin{array}{l}\text { Gabrielian } \\
{[15]}\end{array}$ & 3 & $200 / 185$ & $\begin{array}{l}\mathrm{PC}, \\
\text { treatment }\end{array}$ & $\begin{array}{l}\text { standardised } \\
\text { extract; } \\
\text { AP/ES } \\
\text { combination }\end{array}$ & 60 & 5 & $\mathrm{~N} / \mathrm{A}$ & $\begin{array}{l}\text { greater improvement in mean } \\
\text { symptom score compared with } \\
\text { placebo at day } 5(p<0.001)\end{array}$ \\
\hline $\begin{array}{l}\text { Caceres } \\
{[14]}\end{array}$ & 5 & $208 / 208$ & $\begin{array}{l}\mathrm{R}, \mathrm{PC} \\
\text { treatment }\end{array}$ & $\begin{array}{l}\text { standardised } \\
\text { extract }\end{array}$ & 60 & 5 & 48 & $\begin{array}{l}\text { improvements in all symptoms } \\
\text { compared with placebo }(p<0.03)\end{array}$ \\
\hline $\begin{array}{l}\text { Melchior } \\
\text { [17] }\end{array}$ & 3 & $50 / 50$ & $\begin{array}{l}\mathrm{R}, \mathrm{PC}, \\
\text { treatment }\end{array}$ & $\begin{array}{l}\text { standardised } \\
\text { extract }\end{array}$ & 60 & 5 & 72 & $\begin{array}{l}\text { fewer days sick leave compared with } \\
\text { placebo after five days }(p<0.03)\end{array}$ \\
\hline $\begin{array}{l}\text { Hancke } \\
{[16]}\end{array}$ & 3 & $59 / 59$ & $\begin{array}{l}\mathrm{PC}, \\
\text { treatment }\end{array}$ & $\begin{array}{l}\text { standardised } \\
\text { extract }\end{array}$ & 48 & 5 & 72 & $\begin{array}{l}\text { decrease in summary scores for signs } \\
(p<0.05) \text { and symptoms }(p<0.01) \\
\text { compared with placebo after four days }\end{array}$ \\
\hline $\begin{array}{l}\text { Thamlikitkul } \\
\text { [19] }\end{array}$ & 3 & $152 / 142$ & $\begin{array}{l}\mathrm{R}, \mathrm{C}, \\
\text { treatment }\end{array}$ & $\begin{array}{l}\text { crude } \\
\text { drug (high } \\
\text { or low dose) } \\
\text { or } \\
\text { paracetamol }\end{array}$ & $\begin{array}{l}180 \\
\text { or } 360\end{array}$ & 7 & $\begin{array}{l}\text { not } \\
\text { known }\end{array}$ & $\begin{array}{l}\text { greater eradication of sore throat and } \\
\text { fever in high dose and paracetamol } \\
\text { groups compared with the low dose } \\
\text { group after three days ( } p<0.001) \text {. } \\
\text { No differences between groups after } \\
\text { seven days }\end{array}$ \\
\hline
\end{tabular}

$\mathrm{R}=$ randomised $\mathrm{PC}=$ placebo controlled $\mathrm{C}=$ comparative.

ache, fatigue, earache, sleep disturbance, soreness of throat, nasal secretion, expectoration and frequency and intensity of cough on a visual analogue scale, within 48 hours of the onset of symptoms and after two and four days of treatment with either $A$. paniculata (60 mg andrographolide/day) or placebo [14]. Compared with placebo, fatigue, sleep disturbance, nasal secretion and soreness of throat $(\mathrm{p}<0.03)$ were all improved after two days of treatment; on day four there were significantly greater improvements in all symptoms (all $\mathrm{p}<0.01$ ).

Fifty adult patients with uncomplicated URTI received a standardised extract of $A$. paniculata (andrographolide $60 \mathrm{mg} /$ day) or placebo within 72 hours of the onset of symptoms in a randomised, double-blind, placebo-controlled trial [17]. Although the primary outcome measures were patient- and physician-evaluated symptom scores, these are not reported, instead the results are presented as several summary measures. After five days of treatment, there was a significant difference between groups in the number of sick leave days reported and the number of patients who declared themselves 'totally recovered' (0.96 vs. $0.21 ; \mathrm{p}<0.03$ and 67.5 vs. $36 \%$; $<0.046$ ).

Hancke et al. conducted a non-randomised, placebo-controlled double-blind study of 59 adult patients diagnosed with common cold [16]. Within 72 hours of the onset of symptoms, patients received treatment with either a standardised extract of $A$. paniculata (andrographolide $48 \mathrm{mg} /$ day) or placebo for five days. After four days of treatment there was a decrease in summary scores for signs ( $\mathrm{p}<0.05)$ and symptoms ( $\mathrm{p}<0.01)$ compared with placebo. Both groups showed significant reductions in shivering, sore throat and muscular ache; in addition, treatment with $A$. paniculata was associated with reductions in the strength of the disease, tiredness, rhinitis, sinus pains and headaches.

In a comparative study, 152 patients with sore throat and either a history of fever or a temperature of at least $37.8^{\circ} \mathrm{C}$ were randomised to receive encapsulated dried leaves of $A$. paniculata (andrographolide 180 or $360 \mathrm{mg} /$ day) or paracetamol $(3.9 \mathrm{~g} /$ day $)$ for seven days [19]. The study medications were prepared in identical capsules. There was a significant difference in efficacy in favour of paracetamol and high dose A. paniculata for eradication of sore throat and fever at day three $(\mathrm{p}<0.001)$. By day seven there were no significant differences between the groups with almost all patients being symptom-free.

\section{Evaluation of safety}

Spontaneous reporting schemes: As of June 2003, no reports of suspected adverse events associated with $A$. paniculata had been received by the national drug safety bodies of the United Kingdom, Germany or Australia. The World Health Organisation Collaborating Centre for International Drug Monitoring provided three reports of anaphylactic shock [1 report] and anaphylactic reaction [2 reports]. All occurred in Sweden in 1996, no further 
Table 2 Adverse events reported during administration of Andrographis paniculata to human subjects

\begin{tabular}{|c|c|c|c|c|c|}
\hline $\begin{array}{l}\text { First author } \\
\text { (reference) }\end{array}$ & $N$ & $\begin{array}{l}\text { Patient } \\
\text { population }\end{array}$ & $\begin{array}{l}\text { Study } \\
\text { design }\end{array}$ & $\begin{array}{l}\text { Daily dose } \\
\text { of } \\
\text { andrographolide } \\
\text { (mg) }\end{array}$ & Adverse events experienced (cases) \\
\hline
\end{tabular}

Active treatment

Placebo

\begin{tabular}{|c|c|c|c|c|c|c|}
\hline Melchior [18] & 47 & URTI & $R, D B, P C$ & 60 & no adverse events reported & $\begin{array}{l}\text { no adverse events } \\
\text { reported }\end{array}$ \\
\hline Melchior [18] & 180 & URTI & $R, D B, P C$ & 60 & $\begin{array}{l}\text { unpleasant sensations in the chest (1), } \\
\text { intensified headache (1) }\end{array}$ & $\begin{array}{l}\text { no adverse events } \\
\text { reported }\end{array}$ \\
\hline Gabrielian [15] & 200 & URTI & DB, PC & 60 & $\begin{array}{l}\text { increased nasal discharge and } \\
\text { epigastric pain ( } 1) \text {, blocked nose (1), } \\
\text { severe headache ( } 1 \text { ) }\end{array}$ & $\begin{array}{l}\text { no adverse events } \\
\text { reported }\end{array}$ \\
\hline
\end{tabular}

$\begin{array}{lll}\text { Calabrese [20] } \quad 18 \quad \text { HIV positive (13) } \\ & \text { and healthy } \\ & \text { volunteers (5) }\end{array}$

$5 \mathrm{mg} / \mathrm{kg}$ and
$10 \mathrm{mg} / \mathrm{kg}$
increasing every
3 weeks

allergic reaction (2), fatigue (6),

no placebo group

headache (5), pruritis/rash (12),

diarrhoea (5), nausea (1), metallic taste

(6), bitter taste (2), decreased/no taste

(6), dry tongue (1), decreased sex drive

(1), eyes sensitive to light (1), decreased

short term memory (1), dizziness (1),

heartburn (1), tender lymph nodes (3), lymphadenopathy (2)

$\begin{array}{lcllcl}\text { Panossian [21] } & 16 & \begin{array}{l}\text { healthy } \\ \text { volunteers }\end{array} & \text { O, SD, R } & 20 \\ \text { Caceres [14] } & 208 & \text { URTI } & \text { R, DB, PC } & 60\end{array}$

no adverse events reported

no adverse event information provided

no adverse events reported

no adverse event

information

provided

$\begin{array}{lcllll}\text { Caceres [35] } & 107 & \begin{array}{l}\text { healthy } \\ \text { students }\end{array} & \text { R, DB, PC } & 11 & \begin{array}{l}\text { no adverse event information provided; } \\ \text { no withdrawals }\end{array} \\ \text { Melchior [17] } & 50 & \text { URTI } & \text { R, DB, PC } & 60 & \text { urticaria (2) }\end{array}$

adverse event

information

provided; no

withdrawals

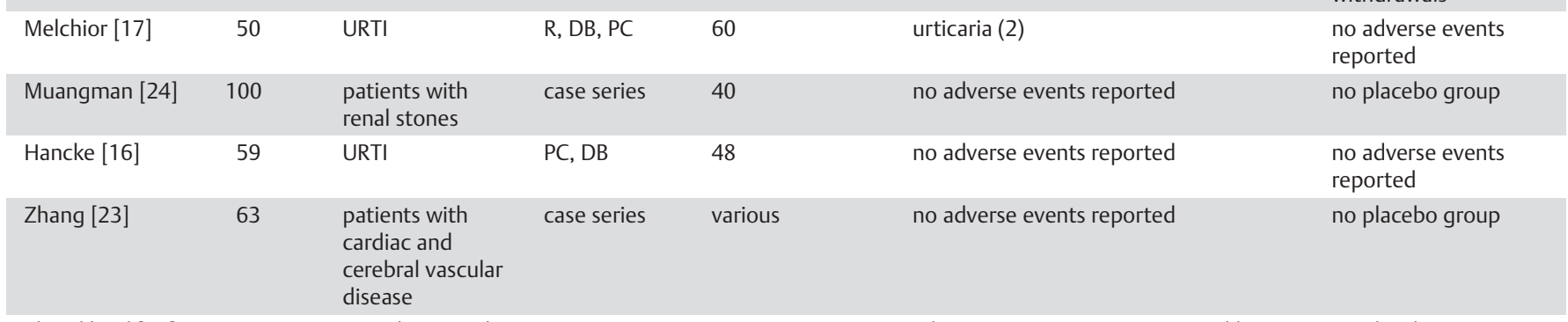

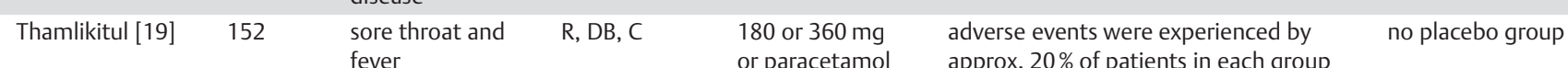

and included nausea, vomiting,

abdominal discomfort, dizziness,

drowsiness and malaise

\begin{tabular}{|c|c|c|c|c|c|c|}
\hline & & & & & ( & \\
\hline Leelarasamee [22] & 10 & $\begin{array}{l}\text { healthy } \\
\text { volunteers }\end{array}$ & $S D, R, C O$ & not known & $\begin{array}{l}\text { no adverse event information } \\
\text { provided }\end{array}$ & $\begin{array}{l}\text { no adverse event } \\
\text { information } \\
\text { provided }\end{array}$ \\
\hline Vedavathy [25] & 25 & $\begin{array}{l}\text { children with } \\
\text { infective hepatitis }\end{array}$ & case report & not known & $\begin{array}{l}\text { no adverse event information } \\
\text { provided }\end{array}$ & $\begin{array}{l}\text { no adverse event } \\
\text { information } \\
\text { provided }\end{array}$ \\
\hline
\end{tabular}

$\mathrm{R}=$ randomised; $\mathrm{O}$ = open; $\mathrm{DB}=$ double-blind; $\mathrm{PC}$ = placebo-controlled; $\mathrm{SD}$ - single dose

reports had been received. The World Health Organisation states that the information provided is not homogeneous at least with respect to origin or likelihood that the pharmaceutical product caused the adverse reaction and that the information does not represent the opinion of the World Health Organisation.

Data from manufacturers: Information was received from one of the four manufacturers/distributors of Andrographis paniculata products contacted; the Swedish Herbal Institute. As of 1981, they had received five reports of adverse events (allergic reactions). No further information was available.
Clinical trials and case series: Adverse events were reported in five of the thirteen clinical trials identified. A phase I trial of HIV-positive patients and healthy volunteers, was terminated early due to the large number of adverse events [20]. A contributing factor may have been the dose of andrographolide used (5$10 \mathrm{mg} / \mathrm{kg} /$ day) which was in the region of six to twelve times higher than that used in all the other studies (e.g., $60 \mathrm{mg} /$ day). Adverse events reported in the remaining trials were mild, infrequent and reversible. In three trials no adverse events were experienced by any of the patients in either the treated or placebo groups and the remaining three reports contained no informa- 
tion regarding adverse events. No adverse events were reported in any of the case series

Experimental studies: Several animal studies were identified which suggest that $A$. paniculata may have contraceptive or antifertility effects following long-term treatment at high doses [26], [27], [28]. However, there is a large degree of discrepancy in the results, with some studies [29], [30] demonstrating no untoward effects even at doses 1000 times those used therapeutically, possibly due to the type of extracts used and the techniques employed to detect change. More work is needed in this area, but the evidence to date suggests that $A$. paniculata should not be taken during pregnancy or by men or women attempting to achieve conception.

\section{Discussion}

A paniculata alone or in combination with E. senticosus appears promising in the treatment of subjective symptoms of uncomplicated upper respiratory tract infection. Short-term therapy at recommended doses is associated with an encouraging safety profile, although adverse events have been demonstrated at higher doses.

This review represents the first attempt to systematically collate the available data on A. paniculata, in many countries a relatively unknown and little studied herb, in an area of medicine in which most current conventional treatment options are largely ineffective. The trials included within the review were large, well designed and of good to excellent methodological quality, and the safety data represent all available information surrounding the incidence of adverse events following administration of $A$. paniculata. We were unable to formally combine the data from individual trials in a meta-analysis as the most appropriate primary outcome measure, sum score for patient-reported symptoms, was available for only four of the trials, and attempts to retrieve this data for the remaining trials from the manufacturer/ authors were unsuccessful.

Several shortcomings of the review need to be addressed. Firstly, with the exception of Thamlikitkul et al. [19], all the trials involved a standardised extract of $A$. paniculata manufactured by the same herbal company, a representative of whom is a co-author on each of the papers. Pooling a relatively small number of trials of this nature may be prone to error and potential bias. Secondly, although attempts were made to obtain data from unpublished trials by contacting authors/manufacturers and searching the Index of Conference Proceedings, none were located. There is evidence to suggest that studies with significant positive results are more likely to be published [31] and this may be more pronounced with an unfamiliar therapy such as A. paniculata. Finally, the safety data should be interpreted with some degree of caution. Generally, adverse events experienced during clinical trials were mild and infrequent, however, trials designed to assess efficacy rarely collect rigorous information on adverse events. Typically each trial includes a relatively small number of patients exposed for a short period of time thus reducing the possibility of observing rare or delayed adverse events. There have also been very few adverse events reported to the various surveillance bodies and manufacturers. There is evidence that patients do not report all adverse events experienced after taking over-the-counter medications whether herbal or conventional [32] and that hospital doctors under-report adverse events [33]. We do not have any figures for the number of patients exposed to $A$. paniculata and the lack of reports could indicate a lack of awareness or availability of the herb. On the other hand, the Australian surveillance body reported that Andrographis paniculata was present in 22 of the products listed on the Australian Register of Therapeutic Goods; none of which was associated with reports of adverse events.

Studies in vitro suggest that A. paniculata may have several potential mechanisms of action relevant in the treatment of acute upper respiratory tract infections including anti-inflammatory [5], [6], [34], immunostimulant [10] and anti-pyretic effects [7], [8]. Although, A. paniculata has been reported to inhibit viral replication in HIV infected cells [20], there are no published data of similar effects with respiratory viruses. As viral replication in the upper respiratory tract is believed to peak on the first day of symptoms, it is unlikely in these trials, where treatment was initiated 36 to 72 hours after the onset of symptoms, that an antiviral mechanism of action was involved.

In conclusion, these data suggest that $A$. paniculata may be a promising treatment for the alleviation of subjective symptoms of acute upper respiratory tract infection. In addition, short-term treatment, at recommended doses, is associated with few reports of adverse events. In light of the lack of effective therapeutic options for acute upper respiratory tract infection, $A$ paniculata is a herbal treatment option that is worthy of consideration for further research.

\section{Acknowledgements}

JTC was supported by a research fellowship provided by Pharmaton SA, Lugano, Switzerland.

\section{References}

${ }^{1}$ Morbidity statistics from general practise; 4th National Survey 1991 1992. Office of Population Censuses and Surveys, 1995 London, HMSO:

2 Fahey T, Stocks N, Thomas T. Systematic review of the treatment of upper respiratory tract infection. Arch Dis Child 1998; 79: 225 - 30

3 Neu HC. The crisis in antibiotic resistance. Science 1992; 257: 1064-73

${ }^{4}$ Kessler RC, Davis RB, Foster DF, Van Rompay M, Walters EE, Wilkey SA et al. Long term trends in the use of complementary and alternative medical therapies in the United States. Ann Intern Med 2001; 135: $262-8$

${ }^{5}$ Shen YC, Chen CF, Chiou WF. Andrographolide prevents oxygen radical production by human neutrophils: possible mechanism (s) involved in its anti-inflammatory effect. Br J Pharmacol 2002; 135: 399-406

${ }^{6}$ Amroyan E, Gabrielian E, Panossian A, Wikman G, Wagner H. Inhibitory effect of andrographolide from Andrographis paniculata on PAFinduced platelet aggregation. Phytomedicine 1999; 6: 27 - 31

${ }^{7}$ Madav S, Tripathi HC, Tandan SK, Mishra S. Analgesic, antipyretic and antiulcerogenic effect of andrographolide. Indian J Pharm Sci 1995; 57: $121-5$

${ }^{8}$ Vedavathy S, Rao KN. Antipyretic activity of six indigenous medicinal plants of Tirumala Hills, Andhra Pradesh, India. J Ethnopharmacol $1991 ; 33: 193-6$ 
${ }^{9}$ Chang RS, Ding L, Chen GQ Pan QC, Zhao ZL, Snith KM. Dehydrographolide succinic acid monoester as an inhibitor against the human immunodeficiency virus. Proc Soc Exp Biol Med 1991; 197: 59-66

${ }^{10}$ Puri A, Saxena R, Saxena RP, Saxena KC, Srivastava V, Tandon JS. Immunostimulant agents from Andrographis paniculata. J Nat Prod 1993; 56: $995-9$

${ }^{11}$ Reynolds JEJ, editor. Martindale: The Extra Pharmacopoeia. London: The Royal Pharmaceutical Scoiety, 1996

${ }^{12}$ Rote Liste ${ }^{\circledR}$ Service GmbH, Frankfurt. Rote Liste 1999. Aulendorf, Germany: Editio Cantor Verlag, 1999

${ }^{13}$ Jadad AR, Moore A, Carroll D, Jenkinson C, Reynolds DJ, Gavaghan DJ et al. Assessing the quality of reports of randomised clinical trials: Is blinding necessary? Controlled Clinical Trials 1996; 17: 1-12

${ }^{14}$ Caceres DD, Hancke JL, Burgos RA, Sandberg F, Wikman GK. Use of visual analogue scale measurements (VAS) to assess the effectiveness of standardised Andrographis paniculata extract SHA-10 in reducing the symptoms of common cold. A randomised double blind placebo study. Phytomedicine 1999; 6: 217-23

${ }^{15}$ Gabrielian E, Shukarian AK, Goukasova G, Chandanian GL, Panossian AG, Wikman $G$ et al. A double blind, placebo controlled study of Andrographis paniculata in fixed combination Kan Jang in the treatment of acute upper respiratory tract infections including sinusitis. Phytomedicine 2002; 9: 589-97

${ }^{16}$ Hancke JL, Burgos RA, Caceres DD, Wikman G. A double blind study with a new monodrug Kan Jang: decrease of symptoms and improvement in the recovery from common colds. Phytotherapy Research 1995; 9: 559-62

${ }^{17}$ Melchior J, Palm S, Wikman G. Controlled clinical study of standardised Andrographis paniculata extract in common cold - a pilot trial Phytomedicine 1996; 3: $315-8$

${ }^{18}$ Melchior J, Spasov AA, Ostrovskij OV, Bulanov AE, Wikman G. Double blind, placebo controlled pilot and Phase III study of activity of standardised Andrographis paniculata Herba Nees extract fixed combination (Kan jang) in the treatment of uncomplicated upper respiratory tact infection. Phytomedicine 2000; 7: $341-50$

${ }^{19}$ Thamlikitkul V, Dechatiwongse T, Theerapong S, Chantrakul C, Boonroj P, Punkrut W et al. Efficacy of Andrographis paniculata, Nees for pharyngotonsillitis in adults. J Med Assoc Thai 1991; 74: 437-42

20 Calabrese C, Berman SH, Babish JG, Ma X, Shinto L, Dorr M et al. A phase I trial of andrographolide in HIV positive patients and normal volunteers. Phytotherapy Research 2000; 14: 333-8

${ }^{21}$ Panossian A, Hovhannisyan A, Mamikinyan G, Abrahamian H, Hambardzumyan E, Gabrielian E et al. Pharmacokinetic and oral bioavailability of andrographolide from Andrographis paniculata fixed combination Kan Jang in rats and human. Phytomedicine 2000; 7: 351 -64
${ }^{22}$ Leelarasamee A, Trakulsomboon S, Sittisomwong N. Undetectable anti-bacterial activity of Andrographis paniculata (Burma) Wall. ex Ness. J Med Assoc Thai 1990; 73: 299-304

${ }^{23}$ Zhang Y-Z, Tang J-Z, Zhang Y-J et al. Study of Andrographis paniculata extracts on antiplatelet aggregation and release reaction and its mechanism. Chin J Int Med 1994; 14: 5

${ }^{24}$ Muangman V, Viseshsindh V, Ratana-Olarn K, Buadilok S. The usage of Andrographis paniculata following extracorporeal shock wave lithotripsy (ESWL). J Med Assoc Thai 1995; 78: 310-2

${ }^{25}$ Vedavathy S, Rao DN. Herbal folk medicine of Tirumala and Tirupati region of Chittoor district, Andhra Pradesh. Fitoterapia 1995; 66: $167-71$

${ }^{26}$ Kuwashima K, Kaneko H, Nakanishi K. Studies of clinical effects of ginseng: 1st report; a double blind study of unsettled complaint improving effect of ginseng. Proceedings of the 3rd International Ginseng Symposium, 1980: 187-91

${ }^{27}$ Akbarsha MA, Manivannan B, Hamid KS, Vijayan B. Antifertility effect of Andrographis paniculata (Nees) in male albino rat. Indian J Exp Biol 1990; 28: 421-6

${ }^{28}$ Akbarsha MA, Murugaian P. Aspects of the male reproductive toxicity/ male antifertility property of andrographolide in albino rats: effects on the testis and the cauda epididymidal spermatozoa. Phytotherapy Research 2000; 14: $432-5$

29 Panossian A, Kochikian A, Gabrielian E, Muradian R, Stepanian H, Arsenian $\mathrm{F}$ et al. Effect of Andrographis paniculata extract on progesterone in blood plasma of pregnant rats. Phytomedicine 1999; 6: 157-62

${ }^{30}$ Burgos RA, Caballero EE, Sanchez NS, Schroeder RA, Wikman GK, Hancke JL. Testicular toxicity assessment of Andrographis paniculata dried extract in rats. J Ethnopharmacol 1997; 58: 219-24

${ }^{31}$ Easterbrook PJ, Berlin JA, Gopalan R, Matthews DR. Publication bias in clinical research. Lancet 1991; 337: 867-72

32 Barnes J, Mills SY, Abbot NC, Willoughby M, Ernst E. Different standards for reporting ADRs to herbal remedies and conventional OTC medicines: face to face interviews with 515 users of herbal medicines. Br J Clin Pharmacol 1998; 45: 96-500

${ }^{33}$ Smith CC, Bennett PM, Pearce HM et al. Adverse drug reactions to a hospital general medical unit meriting notification to the Committee on Safety of Medicines. Br J Clin Pharmacol 1996; 42: 423-9

${ }^{34}$ Habtemariam S. Andrographolide inhibits the tumour necrosis factor$\alpha$-induced upregulation of ICAM-1 expression and endothelial-monocyte adhesion. Phytotherapy Research 1998; 12: $37-40$

35 Caceres DD, Hancke JL, Burgos RA, Wikman GK. Prevention of common colds with Andrographis paniculata dried extract. A pilot double blind trial. Phytomedicine 1997; 4: $101-4$ 